This is an open access article under the CC BY-NC-ND license

Issue IV, 22 November 2021

e-ISSN 2707-9481

Institute of Metallurgy and Ore Beneficiation, Satbayev University, Almaty, Kazakhstan

ISBN 978-601-323-252-2

https://doi.org/10.31643/2021.09

\author{
Aiman Nurgaliyeva \\ Senior lecturer, Kh. Dosmukhamedov University of Atyrau, Kazakhstan \\ Email: a.nurgaliyeva@asu.edu.kz \\ ORCID: https://orcid.org/0000-0003-0995-9640
}

\title{
The role of teaching practicum in the future biology teachers' professional training
}

\begin{abstract}
Currently, education is moving towards a modern quality standard, which implies the improvement of the training of students of pedagogical universities for their future professional activity. Accordingly, the priority is given to the problem of training future teachers in the period of teaching practicum, the potential of which is crucial as a "vital foundation" for personal experience in determining professional interests and needs, in mastering the methods of educational activities. In this regard, the scientific problem of training students for self-realization in the context of teaching practicum within a certain pedagogical system will contribute to the expansion and enrichment of the research area of pedagogical science and practice.
\end{abstract}

Keywords: teaching practicum, professional activities, competency, biology teacher, student, education.

Cite this article as: Nurgaliyeva A. (2021). The role of teaching practicum in the future biology teachers' professional training. Challenges of Science. Issue IV, 2021, pp. 61-66. https://doi.org/10.31643/2021.09

\section{Introduction}

Social demand is expressed in the requirements for the training of a new generation of teachers capable of innovative professional activities, possessing the necessary level of methodological culture and readiness for a continuous education throughout life.

Modern teachers will have to meet new challenges. The place and role of teachers in modern society will change. We can say with certainty that the socio-professional status of teachers in society becomes more important, and the social self-esteem of teachers and their assessment by society have become higher.

As a result, the requirements for future teachers' training are constantly increasing. In general, the structure and the content of training should be aimed at the personal development of teachers and the formation of the professional mentality of young specialists in the context of the realization of the modern requirements of society for the training of educational specialists. Educational specialists have to be capable of carrying out an expanded and systematic cultural reproduction including social attitudes and value orientations.

The purpose of the research is a theoretical and methodological substantiation, development and testing of the effectiveness of the system for training students in the context of teaching practicum.

The above issues caused interest and predetermined the need to solve the following tasks:

1. To supplement and clarify the concepts of "students' teaching practicum" and "future biology teachers' professional training" presented in modern pedagogical literature.

2. To develop questionnaires for $3^{\text {rd }}$ and $4^{\text {th }}$ year biology students. 
3. To analyze the obtained results and to give their interpretation in view of the implementation of the updated biology curriculum for general education secondary schools.

The formation of new teaching culture expressed in competency-based approach makes it possible to bridge the gap between the knowledge, skills and abilities obtained in the course of education. Bridging the gap between training and practice increases the competitiveness of a specialist in the labor market. A competitive specialist with an education of any level must meet all the requirements and global trends in the development of the labor market, be able to quickly adapt to the ever-changing living conditions, have a set of necessary competencies in different areas of human activity (Kirillova, 2003).

The issues of teacher training have always been the focus of attention of leading methodologists, educators, and psychologists (Arlinwibowo et al., 2021). A.Y. Terentyev is one of the first scientists involved in the issues of pedagogical training for teaching special disciplines. He revealed the importance of the above issues, pointed out the need to bring artistic, psychological and pedagogical disciplines closer together, so that students' training will become even more in line with the pedagogical specialization of specialists graduated from a faculty. In her studies, N.S. Davlyatshina solves the problem of improving the level of professional and pedagogical training of visual arts teachers in primary schools. In the study of I.V. Solodukhin, the qualitative improvement in the visual arts teachers' training is associated with the enhancement of its practical and pedagogical orientation (Abdullina, 1990).

The purpose of teaching practicum for students is to be prepared for the main types of professional activities, the implementation of acquired professional knowledge, skills, abilities and professional adaptation, i.e. entering the profession, mastering the social role, professional self-determination, formation of positions, integration of personal and professional qualities.

It is well known that one of the methodological approaches to learning, including professional learning, is the activity approach, which proclaims that the development of any skills and psychological properties occurs when carrying out practical activities.

The analysis shows that in many universities, a continuous teaching practicum accompanies students from the first to the third year of studies, and there is a "school day" in the schedule, during which students are exempted from classes at the university and are in school. Whereas in some universities, "school days" are replaced by "school hours" when students visit a school before or after university classes. Finally, in all pedagogical universities in Kazakhstan, students come to school for state teaching practicum in the eighth semester at the graduation year, often being insufficiently prepared for teaching. What is the reason for such an unpreparedness?

Many Kazakh scientists studying such issues have studied foreign experience (Kulikova, 1997; Isayeva, 2012). Let us consider a comparative analysis of the experience of domestic and foreign higher pedagogical schools. The commission of the U.S. National Association for Education engaged in the issues of teacher education and professional standards defines teaching practicum as the "crucial" aspect of teacher education. This coincides with the vision of such issues in Kazakhstan. Like in Kazakhstan, in many U.S. universities, teaching practicum is focused on the last year of studies; however, it is held during the whole academic year. Practicum has two forms: 1) students are permanent employees of a school and receive about a third of the salary; 2) students work for free under the guidance of a senior teacher, and sometimes replace him/her. Obviously, the first form provides a fundamentally different motivation, responsibility and quality. Currently, the tendency to conduct practicum during all years of study is becoming more and more popular.

The students of Kazakh institutions of higher education are trained for teaching at school by studying the curriculum of psychological and pedagogical disciplines such as "Introduction to the teaching profession", "Age physiology and school hygiene", "Pedagogy", etc. However, it is no secret that they provide theoretical training. In the USA, great importance is attached to observation as the preparatory and initial stage of the practicum. For this, numerous schemes have been developed for analyzing teachers' activities in classroom, and school television is used to enable observing and analyzing a lesson without interfering with its natural course. In addition, the most remarkable is that in the American system of teacher education, the responsibility for organizing and conducting practical training of students lies with schools and school teachers (Hwopek, 1975; Coker \& Schrader, 2004; Stimpson, Lopez-Real, Bunton, Chan, Sivan et al., 2000).

In German universities, there is a similar tradition to Kazakhstan when, during a teaching practicum, student teachers attend school lessons on a weekly basis and then discuss them under the guidance of a 
university teacher. The teaching practicum can last up to 3 years. Nevertheless, the peculiarity is that this practice is organized in such a way that future teachers get a full-time job at the school. Their teaching activities are supervised by experienced teachers and methodologists. After completing the practical training cycle, a future teacher passes the state exam (a second one), which contains a test of the theory, skills and abilities to conduct academic work at school (Schulz, 2005; Wankat \& Oreovicz, 2001).

The time limits of teaching practicum for future teachers in the UK are on average $25 \%$ of the total amount of study time (from 18 to 32 weeks). The names of the teaching practicums of British students echoes Kazakh ones: they are observational practice, internship, and work placement. However, the fundamental difference is that practicum takes place in schools before students begin to study the theoretical disciplines of the psychological and pedagogical curriculum. Experienced schoolteachers (mentors) and teachers of colleges and universities (tutors) supervise the work of students during teaching practicum. In this case, the tutors do not directly supervise the student teaching practicum but receive information from the mentors about the results of the work of student teachers.

In the UK, there are two main forms of teaching practicum at school: traditional (long-term practicum without attending university classes) and serial (short-term practicum conducted together with university classes, which can last half a day, a day, or a week). Teaching practicum includes attending school in order to study the peculiarities of the educational process, review and analysis of demonstration lessons, micro-teaching, and independent conducting of classes (Lawson, Çakmak, Gündüz, \& Busher, 2015; Sprague \& Percy, 2014; Farrell, 2007).

When summarizing the main differences in the organization of practicum in Kazakh and other systems of teacher education, two conclusions can be drawn: 1) the ratio of theoretical and practical training of students varies significantly; 2) outside Kazakhstan, the responsibility for the management (including grading) of the student teaching practicum lies, to a greater extent, with schools.

These differences would be understandable if there were not a paradox: the first difference fully corresponds to the activity approach, which is proclaimed fundamental for the Kazakh educational system.

\section{Materials and Methods}

Teaching practicum is a complex process in which students perform activities defined by their specialization.

The objectives and scope of a practicum are determined by the relevant state educational standards for the levels of higher professional education.

Teaching practicum tasks can be formulated as follows:

- enhancement and consolidation of theoretical knowledge, its application in solving specific sociopedagogical tasks;

- formation of analytical thinking, the ability to predict and model professional activities in a changing society;

- formation of a motivational-value attitude to future biology teacher activities, an orientation towards communication and interaction with the student team during studies, the need for self-realization;

- mastering the content and various forms and methods of organizing individual, group, and collective activities of children of different ages, techniques of carrying out the work with a student team;

- acquisition of the ability to conduct individual educational work with students who have learning, interpersonal communication problems etc.;

- creation of conditions for the improvement of diagnostic, communication, organizational, analytical skills and professionally significant personal qualities of biology teachers;

- formation of skills to establish professional and ethical relationships with colleagues.

In combination with academic disciplines, the practical activity of students contributes to defining orientations and prospects for professional growth in the future, strengthening the adequate professional self-esteem, and shaping the future teachers' personalities (Bailey, Scantlebury, \& Johnson, 1999; Ryan, Toohey, \& Hughes, 1996; Head, 1992).

In practice, the pedagogical activity of students is improved on the basis of substantial factual material, the learning and effective mastering of which is possible only with the use of live impressions and observations ("The Teaching of Style," 1972; Pfeiffer \& Reighard, 1971; Belliveau, 2007; Taylor \& Miller, 1985). 
Important factors in students' teaching practicum are:

- students' ability to change their social and professional activities understood as the most important personal quality, which expresses a creative attitude to various aspects of life including selfattitude. Teaching practicum determines what is the focus of these activities in the professional sphere;

- versatile orientation of future teachers to all spheres of pedagogical activities: the discipline-based and educational activities of students and their methodological equipment, the educational interaction, its organization and mastering the research work methodology;

- formation, in the context of the natural pedagogical process, of a reflexive culture, when for a teacher the means and methods of his/her own pedagogical activity, the processes of developing and making practical decisions become the subject of reflection. An analysis of one's own activities helps a practice teacher to become aware of the difficulties encountered in his/her work, and to find competent ways to overcome them.

These factors of the teaching practicum are determined by the following targets:

- development of professional competency of a teacher, personal and humanistic orientation, systemic vision of pedagogical reality;

- formation of content area and reflexive culture;

- mastering pedagogical techniques and the ability to integrate with pedagogical experience.

Organizational and pedagogical conditions of teaching practicum include:

- diagnostic conditions (live and online discussion of contradictions and difficulties in the lasr year students' professional pedagogical activities; highlighting the relevant types and their characteristics);

- projective conditions (development of goals and tasks of teaching practicum focused on the formation of the core teacher competencies, their scientific substantiation, preparation of the basis for teaching practicum, development of criteria for project effectiveness and conditions for implementation);

- conditions of professional self-education (ensuring real professional growth of students through the development of individualized methods, techniques and means of self-education as a form of teacher self-improvement, participation in student scientific and practical conferences, etc.);

- conditions of value and notional attitude to the future profession (interaction with mentors and students; participation in assignments, solving pedagogical tasks etc.) (Zhirkova, 2012; Monakhov, Vlasov, \& Veresova, 2004; Ivanischev, 1989; Black, 1976).

The content of teaching practicum may include the invariant system of tasks aimed at shaping the students' readiness for independent projecting and the implementation of the educational process at school, and the variable part focused on the students' expectations and their creative and scientific interests, tasks that a particular school solves in the process of implementing innovative activities' projects etc. The list of tasks of the variable part can be unlimited. These can be tasks related to participation in management activities, diagnostic studies, building an educational system, organizing exhibition activities, etc.

In the course of teaching practicum, students develop the basis for analyzing and evaluating their own pedagogical activities. Pedagogical reflection develops not only in the work with a teaching practicum log book but in every lesson, in every communication with children. During a practicum, students have to be prepared for real pedagogical activities, where they will have to perform all teacher functions. Indicators of the level of knowledge, skills, personal development and creative activity of students are closely related to the quality of the educational process and are more important for determining the effectiveness of the quality of the educational process.

One of the main tasks of teaching practicum is to study the current state of educational work in educational institutions, that is, monitoring as a constant observation of any process in order to identify its compliance with the desired result.

\section{Results and Discussion}

Teaching practicum is complex and includes the following stages: preparatory, main and final ones.

At the preparatory stage, students are trained to solve the problems of teaching practicum. They get acquainted with the practicum's content and form as well as with parameters for evaluating the success of each stage. Initial conference and seminars can be distinguished among the forms of work.

At the main stage of the practicum, the following tasks can be offered to student teachers: 
- to get acquainted with the educational institution where the practicum is held (to determine the type of school, analyze the main areas of work and the pedagogical process);

- to study the class, to get acquainted with the work of teachers and the class teacher; to study individual students;

- to conduct a non-standard lesson, take part in the discussion and analysis of non-standard lessons;

- to analyze extracurricular activities plans;

- to study the class using basic psychological methods, to make a psychological and pedagogical characteristics and diagnostic card of the class;

- take part in school-wide educational activities.

The implementation of this stage can be carried out in the following forms:

- meeting with the administration and teaching staff of the school,

- work with regulatory documents,

- visiting lessons, group discussion of lessons, general pedagogical and psychological-pedagogical analysis of lessons,

- questioning the relationship and the situation of students in the class, filling in a diagnostic card, drawing up the psychological and pedagogical characteristics of students' personalities,

- conducting a non-standard lesson,

- filling in the teaching practicum log book,

- consultations with mentor teachers, group leaders, etc.

At the final stage, the results of the teaching practicum and the preparation of reporting documentation are carried out; prospects for further professional growth are determined. Summing up takes place at the final conference (Kirillova, 2003).

\section{Conclusion}

Thus, it can be concluded that modern pedagogical education meets the needs of a dynamically developing society and is actively seeking new alternative forms of professional training for students. The modern professional training should create the most favorable conditions for the development of student personality, meet the increased requirements for modern teachers, their professional and personal qualities, as well as ensure a high level of competency and mobility of students.

There is a problem of students' professional readiness and insufficiently formed professional pedagogical values. The difficulties encountered by students during the teaching practicum, show the inability to integrate knowledge from discipline-based, psychological and cultural areas (Milrud, 1997; Falileyeva, 1989; Dorofeyev, 1989). The ability to apply this knowledge in practice is also a challenge. The questionnary survey showed that student teachers are dissatisfied with their knowledge of pedagogy, psychology, and methods of teaching their discipline. This is alarming since these facts once again prove that the traditional training of teaching staff must change by acquiring new forms.

Thus, after analyzing the current state of the Kazakh education system including the latest innovative approaches and the features of organizing teaching practicum in other countries, the authors highlight areas for the further development of practicum at school:

- undergoing teaching practicum during all years of studies;

- a gradual increase in the duration of teaching practicum from year to year of studies in order to adapt students to the reality of school life;

- a gradual increase in the responsibility of schools for teaching practicum;

- enhancing the collaborative interaction of school and university teachers to improve teaching practicum programs;

- stimulation of this type of work for school teachers (for example, material incentives, advantages in certification, etc.).

Cite this article as: Nurgaliyeva A. (2021). The role of teaching practicum in the future biology teachers' professional training. Challenges of Science. Issue IV, 2021, pp. 61-66. https://doi.org/10.31643/2021.09 


\section{References}

Abdullina, O. A. (1990). Obshchepedagogicheskaya podgotovka uchitelya v sisteme vysshego pedagogicheskogo obrazovaniya [General pedagogical training of teachers in the system of higher pedagogical education]. Moscow: Prosveshcheniye.

Arlinwibowo, J., Retnawati, H., Hadi, S., Kartowagiran, B., \& Kassymova, G. K. (2021). Optimizing of item selection in computerized adaptive testing based on efficiency balanced information. Journal of Theoretical and Applied Information Technology, 99(4), 921-931.

Bailey, B., Scantlebury, K., \& Johnson, E. (1999). Encouraging the Beginning of Equitable Science Teaching Practice: Collaboration is the Key. Journal of Science Teacher Education, 10(3), 159-173.

Hwopek, D. (1975). Individualizing the Student Teaching Practicum: A Group Program Model. English Education, 6(3), $169-172$.

Kirillova, I. V. (2003). Sistema podgotovki studentov $k$ samorealizatsii v usloviyakh pedagogicheskoy praktiki [System of training students for self-realization in the context of teaching practicum] (Unpublished doctoral dissertation). Saratov.

Kulikova, L. M. (1997). Organizatsiya nepreryvnoy pedagogicheskoy praktiki studentov zarubezhnykh vysshikh uchebnykh zavedeniy [Organization of continuous teaching practicum for students of foreign higher educational institutions]. Scientific and theoretical journal of the Ural State Academy of Physical Culture, 9. Retrieved from http://lib.sportedu.ru/press/tpfk/1997n9/p52-56.htm

Lawson, T., Çakmak, M., Gündüz, M. \& Busher, H. (2015). Research on teaching practicum - a systematic review. European Journal of Teacher Education, 38(3), 392-407.

Milrud, R. P. (1997). Osnovy psikhologii [Fundamentals of Psychology]. Rostov-on-Don: Feniks.

Schulz, R. (2005). The Practicum: More than Practice. Canadian Journal of Education / Revue Canadienne De L'éducation,28(1/2), 147-167. doi: 10.2307/1602158.

Taylor, G., \& Miller, P. (1985). Professional Course Work and the Practicum: Do Good Students Make Good Teachers? Canadian Journal of Education / Revue Canadienne De L'éducation, 10(2), 105-120. doi: 10.2307/1494269.

Zhirkova, Z. S. (2012). Pedagogicheskaya praktika studentov - podgotovka k osnovnym vidam professionalnoy deyatelnosti [Students' teaching practicum - training for the main types of professional activities]. Fundamentalnyye issledovaniya, 6-2, 360-364. 